Research Article

\title{
Analysis of Deformation Characteristics of Filled Subgrade Treated by Micro-Pile
}

\author{
Xuhe Gao ${ }^{1},{ }^{1}$ Weiping Tian, ${ }^{2}$ Jiachun $L i,{ }^{2}$ Hongliang Qi, ${ }^{2}$ and Zhipei Zhang ${ }^{3}$ \\ ${ }^{1}$ School of Mechanics, Civil Engineering \& Architecture, Northwestern Polytechnical University, \\ Address: No. 1 Dongxiang Road, Chang'an District, Xi'an 710129, Shaanxi, China \\ ${ }^{2}$ Key Laboratory of Highway Engineering in Special Region, Ministry of Education, Chang'an University, \\ Address: No. 126, Middle Section of South Second Ring Road, Beilin District, Xi'an 710064, Shaanxi, China \\ ${ }^{3}$ College of Geology and Environment, Xi'an University of Science and Technology, \\ Address: 58 Yanta Middle Road, Beilin District, Xi'an 710054, Shaanxi, China
}

Correspondence should be addressed to Xuhe Gao; 81706037@qq.com

Received 14 August 2021; Accepted 6 November 2021; Published 24 November 2021

Academic Editor: Jun Zhao

Copyright (c) 2021 Xuhe Gao et al. This is an open access article distributed under the Creative Commons Attribution License, which permits unrestricted use, distribution, and reproduction in any medium, provided the original work is properly cited.

Deformation control of fill subgrade is a difficult point in the field of highway engineering. This article relies on the treatment project of micro-piles for subgrade deformation of K555 + 070 K557 + 710 section of Qingdao-Yinchuan Expressway. Settlement and stress monitoring was carried out at the toe of the roadbed, the shoulder, and the center of the roadbed. We use Midas/GTS modeling trial calculation. A new method to check the simulation results of the deviation rate is proposed. A calculation model of the stress and deformation of the subgrade in the whole life cycle is established. The results of comparative analysis, monitoring, and simulation are as follows. (1) The compression and consolidation of the fill account for most of the settlement and deformation of the roadbed in the whole life cycle. (2) Subgrade center settlement is the sensitive part of subgrade deformation. (3) After piles are added, the deformation extremes at the toe of the slope, the shoulder, and the center of the roadbed are all reduced by more than $96 \%$. The research results can provide theoretical guidance for the analysis of the stress and deformation characteristics of the subgrade before and after the micro-pile treatment.

\section{Introduction}

A micro-anti-slide pile-also known as a "micro-pile"-is a small anti-slide pile with a diameter of less than $300 \mathrm{~mm}$ that can be constructed by drilling a hole, reinforcing the structure, and filling the hole by pressure grouting. As micro-piles are easy and quick to construct and can be flexibly positioned according to the needs of the project, they are widely used in slope engineering projects for reinforcement and slip prevention [1-4]. Though micro-piles were initially used for foundation reinforcement, they have more recently been applied to a variety of advanced engineering projects including landslide treatment and deep foundation pit support [5-7]. In slope reinforcement projects, the ability to construct micro-piles rapidly is particularly valuable in emergency projects, such as those for landslide treatment; furthermore, micro-piles offer an advantage over traditional anti-slide piles as they can be constructed with less disturbance to the slope. Similar to traditional anti-slide piles, micro-piles are under the same force as the rock and soil body following construction and work to maximize the anti-sliding ability of the rock and soil body $[8-10]$.

A variety of previous studies have investigated the applications of micro-piles. Wu et al. [11] studied a combined support system comprised of micro-piles and a concrete sprayed layer, which maximized the uplift capacity of the micro-piles and improved the traditional soilnailed wall support form. Fang et al. [12] explored the antisliding effect of coupling beam single-row anti-slide piles through outdoor model tests. The tests showed that coupling beams can reduce the top displacement and pile body 
damage of micro-piles as well as the shear strength of the sliding surface. Liang et al. [13] investigated two types of pile core and pile circumference reinforcement and found that the moment of inertia of the pile section under the circumference reinforcement is greater than that of the pile core. Zhu et al. [14] conducted a study on the use of miniature anti-slide piles to strengthen the ultimate resistance of a slope and found that miniature anti-slide piles can bear the bending and shearing action for the slope as a whole. Zhu et al. [15] found through experiments that the horizontal bearing capacity of a micro-pile is directly related to the type of slope rock and soil in which it is embedded in addition to the conventionally considered parameters-pile section, flexural rigidity, and pile layout. Esmaeili et al. [16] introduced a successful case of using micro-piles to reinforce the slope of a road embankment in the Commonwealth of Pennsylvania, USA. Chen et al. [17] used numerical simulation methods to study the influence of geotechnical parameters on the bearing capacity of micro-piles and found that the friction angle has the greatest influence on the horizontal bearing capacity of micro-piles.

In summary, there is a clear relationship between the force mechanism of a micro-pile and the pile dimensions, the surrounding rock and soil type, and the nature of the load on the pile. However, evaluating the deformation of a subgrade after micro-pile treatment remains challenging. This study aims to address this challenge by researching the micro-pile treatment of the filled subgrade along the $\mathrm{K} 555+070$ to $\mathrm{K} 557+710$ section of the Qingdao-Yinchuan Expressway. To this end, the deformation and stress of the subgrade were monitored and Midas/GTS software was used to create and validate a numerical simulation of this project based on the monitoring data.

\section{Study Area and Monitoring Setup}

2.1. Study Area. Section $\mathrm{K} 555+070$ to $\mathrm{K} 55+710$ of the Qingdao-Yinchuan Expressway is located in Ningjin County, Hebei Province. The study area is located in the central and southern region of the Jizhong Plain, which is an alluvial plain at the eastern foot of the Taihang Mountains. The terrain is low and flat, sloping slightly from northwest to southeast with a natural slope of $1 / 4000$. The highest elevation in the whole region is $36.5 \mathrm{~m}$ above sea level, and the lowest elevation is $24.4 \mathrm{~m}$ above sea level. The average annual precipitation is $449.1 \mathrm{~mm}$, with large seasonal and interannual differences in precipitation. There are 11 seasonal rivers in the area. The total length of the river is $170.32 \mathrm{~km}$, the density of the river network is $0.16 \mathrm{~km} / \mathrm{km}^{2}$, and the total annual runoff is 3.154 billion cubic meters.

On-site drilling and indoor geotechnical tests of the section $\mathrm{K} 555+070$ to $\mathrm{K} 557+710$ show that the soil in this section is mainly composed of silt, silty clay, and clay, with a layer of medium-fine sand interspersed locally. The topdown soil layers of the studied road section are as follows: (1) asphalt surface layer: $0.7 \mathrm{~m}$; (2) artificial fill: $3.2 \mathrm{~m} \sim 4.5 \mathrm{~m}$; (3) silty clay: $2.7 \mathrm{~m} \sim 4.1 \mathrm{~m}$; (4) silk soil: $2.6 \mathrm{~m} \sim 3.2 \mathrm{~m}$; (5) silty sand: $4.9 \mathrm{~m} \sim 6.0 \mathrm{~m}$; and (6) silty clay: $3.4 \mathrm{~m} \sim 4.0 \mathrm{~m}$.
The K555 + 070 K557 + 710 section of Qingdao-Yinchuan Expressway has seen obvious uneven settlement of subgrade since June 2009. The cracks develop along the direction of the roadbed (see Figure 1), and the cracks are 0.5-15 mm wide. From the appearance of the crack to the micro-pile treatment, the crack continued to expand, and secondary cracks were generated at the cracks, especially in the rainy season. The road maintenance work area once used the cracked pavement to be filled with joints, but the treatment effect was not obvious.

In order to control the continuation of the uneven settlement of the roadbed, it is planned to carry out grouting + root pile reinforcement treatment on the road section. After the construction is completed, the micropile, the grout around the pile, and the original roadbed work together. The strength of the micro-pile body is $\geq 20 \mathrm{MPa}$, and the bearing capacity of a single pile is $\geq 150 \mathrm{KN}$.

According to the filling height of the roadbed, the micro-pile design row spacing is $3 \mathrm{~m}$, the row spacing is 2.5-4.0 $\mathrm{m}$, the pile length is $9.5 \mathrm{~m}$, and the pile diameter is $140 \mathrm{~mm}$. According to field tests, the single-hole grouting radius of the micro-pile is about $1.5 \mathrm{~m}$. The grouting filling factor is 3 to $5 \%$, and the grouting amount per unit length is 0.1875 to $0.4875 \mathrm{~m}^{3}$. The ratio of micro-pile diameter to pile length in this project was small. Thus, under the road load, the pile top will have some perforation effect on the road surface. However, the grouting effect resulting from the micro-pile construction process significantly improves the strength of the soil and the load-bearing capacity of the roadbed.

\subsection{Subgrade Monitoring}

2.2.1. Pressure Monitoring. We implemented a physical test project; to this end, 36 soil pressure boxes were buried in the soil near the 12 micro-pile bodies at the K557+ 348 culverts, and 6 soil pressure boxes were buried in the soil near the 2 micro-pile bodies at K557+680 (Figure 2).

2.2.2. Deformation Monitoring. After the completion of the roadbed construction on August 7, 2011, the K557+000 to $\mathrm{K} 557+680$ section was subdivided into seven cross sections with six observation points each, for a total of 42 observation points. These observation points were used to evaluate the settlement and deformation characteristics of the subgrade. The reference point was located on concrete that is not affected by settlement. It is measured by Leica NA2 automatic level and micrometer with an accuracy of $0.3 \mathrm{~mm} / \mathrm{km}$. We found that the settlement of the subgrade center during the operating period of the roadway and after the micro-pile treatment was $25.60 \mathrm{~cm}$ and $0.55 \mathrm{~cm}$, respectively. The horizontal displacement at the toe of the slope was $4.01 \mathrm{~cm}$ during roadway operation and $0.04 \mathrm{~cm}$ after micro-pile treatment. The horizontal displacement at the shoulder was $2.72 \mathrm{~cm}$ during roadway operation and $0.08 \mathrm{~cm}$ after micropile treatment. 


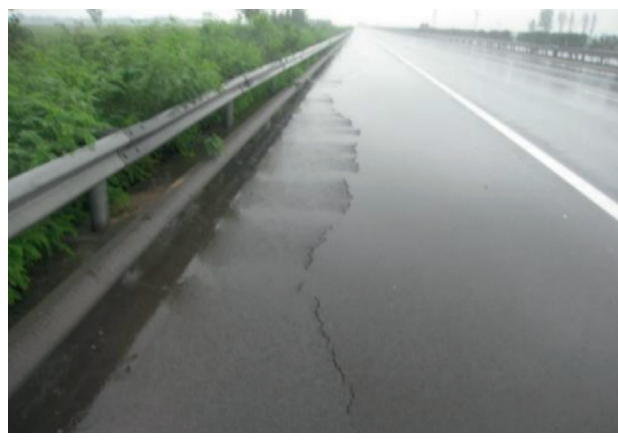

(a)

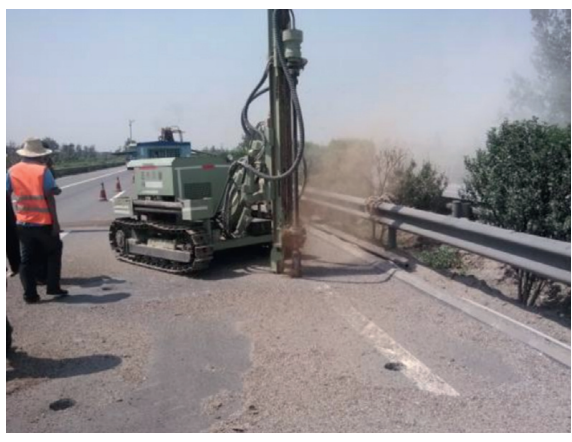

(b)

Figure 1: Longitudinal cracks and drilling rig operation at K555+800 (in Yinchuan direction).

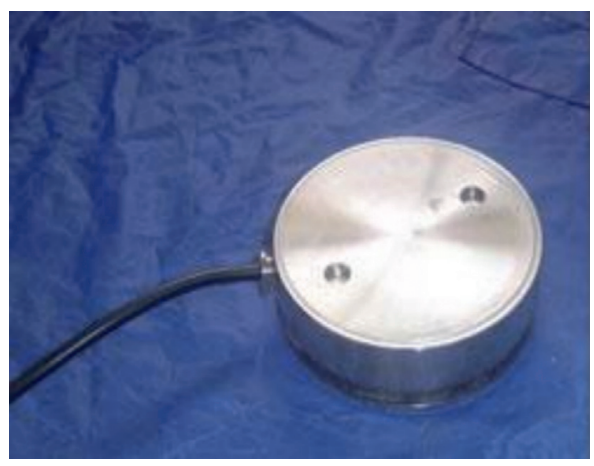

(a)

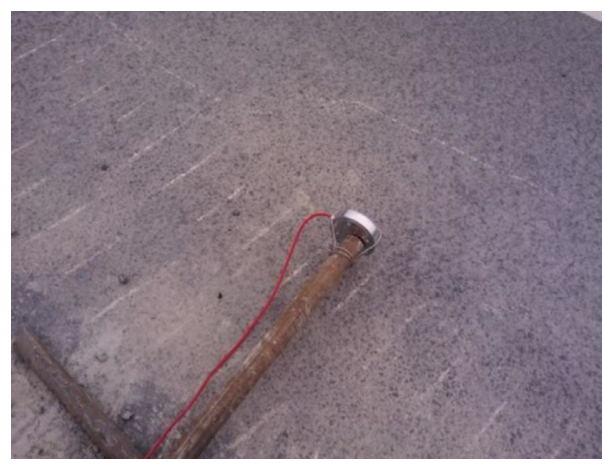

(b)

FIGURE 2: Installation and layout of the earth pressure boxes. (a) XB-150 double-membrane earth pressure cell. (b) Site of earth pressure box installation.

\section{Methods}

\subsection{Calculation Model}

3.1.1. Simulation Assumptions and Regions. We used Midas/ GTS NX software for modeling. Taking into account the complex geological environment as well as the actual filling and treatment of the roadbed in the study area, the following assumptions were made in developing the simulation model:

(1) The rock-soil mass is an ideal elastoplastic body and obeys the Mohr-Coulomb strength yield criterion.

(2) The influence of groundwater and seepage on the whole project is simplified.

(3) The micro-pile is a completely elastic body, and the vehicle load during roadway operation can be simplified to a static load.

(4) The rock-soil-structure interface is defined by the pile contact characteristics. The grouting effect refers to the increase in the strength of the soil around the pile.

After careful consideration, we designed the model to represent a $1 \mathrm{~m}$ section along the roadway with a crosssectional foundation width of $78 \mathrm{~m}$ and a foundation thickness of $30 \mathrm{~m}$. The height of the subgrade filling was
$6.6 \mathrm{~m}$, the top surface of the subgrade was $28.0 \mathrm{~m}$ wide, and the bottom surface was $46.0 \mathrm{~m}$ wide. The micro-piles were spaced $1.625 \mathrm{~m}, 2.50 \mathrm{~m}, 3.75 \mathrm{~m}$, and $4.00 \mathrm{~m}$ from the center of the road. The foundation consisted of five layers of soil. From top to bottom, they were the hard shell layer, clay layer, silt layer (including sand), silt soil layer, and silty clay layer, which were $0.5,2.2,3.2,4.9$, and $4.0 \mathrm{~m}$ thick, respectively. The subgrade fill was divided into five layers with thicknesses of $0.5,2.5,1.5,1.3$, and $0.8 \mathrm{~m}$ from top to bottom. A schematic of the model is shown in Figure 3.

3.1.2. Model Boundary Conditions. The model boundaries and constraints were as follows:

(i) The left and right boundaries of the model are set as $X$-direction constraints such that $u=0$, where $u$ is the $X$-axis direction, $w$ is the $Z$-axis direction, and $v$ is the $Y$-axis direction.

(ii) The front and back boundaries of the model are constraints in the $Z$-direction, such that $w=0$.

(iii) The bottom boundary of the model and the side boundaries of the foundation are fully constrained boundaries, such that $u=0, v=0$, and $w=0$.

(iv) The upper boundary of the model is a free boundary, which is not constrained. 


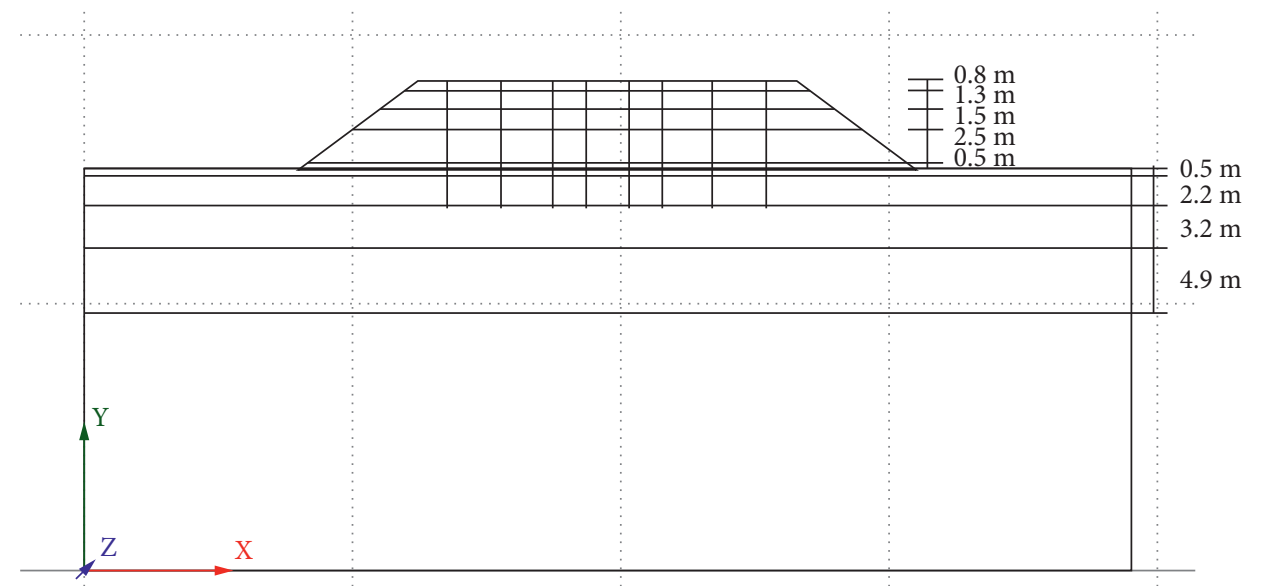

FIGURE 3: Schematic of the calculation model layers $(K 557+680)$.

The initial stress used for model calculations was the selfweight stress of the roadbed. The model was divided into 10552 units and 10758 nodes.

3.2. Calculation Process. We divided our analysis into three stages as follows: completion of roadbed construction (6 months), roadway operation period ( 24 months), and postmicro-pile treatment (12 months). An overview of the calculation process is shown in Figure 4.

3.3. Physical and Mechanical Parameters. The parameters used for the micro-piles were determined according to the construction specifications. Poisson's ratio and unit weight were determined from geotechnical tests. The elastic modulus, friction angle, and cohesion were determined based on geotechnical test data and adjusted based on the deviation rate determined after performing trial calculations. Tables 1 and 2 summarize the model parameters.

3.4. Validation of Calculated Results. The simulation calculations for the existing roadbed are largely dictated by several key geotechnical parameters. Notably, strategies for the selection and determination of model parameters have always been controversial. The current parameter selection methods use data obtained through geotechnical tests, statistical data based on similar strata, or empirical data. However, there are limitations associated with each of these approaches. Since the parameters determined by geotechnical tests differ from the parameters of actual projects, they need to be corrected. The statistical data method is only applicable to ordinary stratum and requires the accumulated knowledge from many similar engineering projects. Finally, empirical data are convenient to use but lack scientific rigor. In short, none of the three existing parameter selection methods can be applied universally, which is a significant limitation for their use in special geological environments. Thus, identifying a method that can use on-site monitoring data to validate the main parameters for theoretical calculations and finite element analysis is very important. We propose validating the simulation parameters by calculating the deviation rate $(P)$. When the deviation rate between the simulation result and the monitored value is within the allowable range $(P<50 \%)$, the physical and mechanical parameters selected by the calculation model can be considered reasonable.

In our study area, on-site monitoring revealed that the settlement of the subgrade center during the roadway operation period and after the micro-pile treatment was $25.60 \mathrm{~cm}$ and $0.55 \mathrm{~cm}$, respectively. The simulation results show that the vertical displacement of the embankment center during the roadway operation period and after the micro-pile treatment was $21.43 \mathrm{~cm}$ and $0.35 \mathrm{~cm}$, respectively. We calculated the deviation rate as (calculated value-monitoring value)/monitoring value and found that the simulated data deviation rate during the operation period was $-16.30 \%<50 \%$; furthermore, the simulated data deviation rate after the micro-pile treatment was $-36.36 \%<50 \%$. Thus, the parameters selected for the simulation are valid.

\section{Results}

The deformation in the direction perpendicular to the ground plane is the most important parameter of uneven settlement and destruction in the process of subgrade filling, operation, and treatment. At the same time, considering the need to use the subgrade settlement data obtained from the previous deformation monitoring to check the simulation results, the $Y$-direction displacement simulation result analysis is selected here.

Taking the centerline of the roadbed as the axis of symmetry, it can be seen in Figures 5-7 that the underside of the side slope on both sides of the roadbed, the side slope line, and the road shoulder are the most concentrated areas of deformation. The settlement pattern of the subgrade center is arcshaped and slopes down to the surroundings, whereas the shoulders on both sides of the center axis shift towards the 


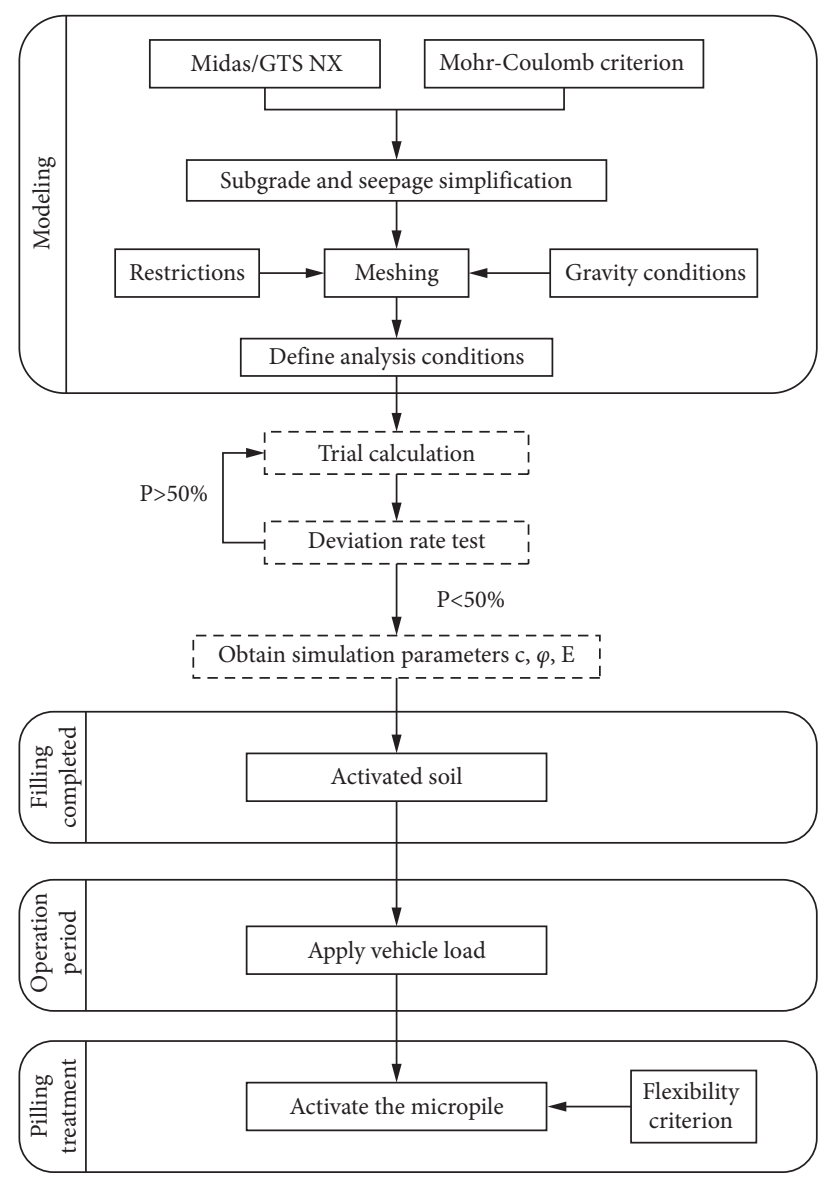

Figure 4: Procedural flowchart for modeling and calculations.

TABle 1: Physical and mechanical parameters of various soil layers.

\begin{tabular}{lccccccc}
\hline Layer number & Soil layer & Layer thickness $(\mathrm{m})$ & Unit weight $\left(\mathrm{kN} / \mathrm{m}^{3}\right)$ & $v(-)$ & $E(\mathrm{MPa})$ & Cohesion $(\mathrm{kPa})$ & Friction angle $\left(^{\circ}\right)$ \\
\hline 1 & Surface clay & 0.5 & 15.7 & 0.3 & 14 & 9 & 10.29 \\
2 & Clay & 2.2 & 19.3 & 0.3 & 11 & 37 & 29.12 \\
3 & Silt (sandy) & 3.2 & 19.5 & 0.3 & 3 & 21 & 21.13 \\
4 & Silt (with shell) & 4.9 & 18.8 & 0.3 & 8 & 25 & 25.45 \\
5 & Silty clay & 4.0 & 18.8 & 0.3 & 8 & 25 & 25.45 \\
\hline
\end{tabular}

TABle 2: Physical and mechanical parameters of the subgrade fill material.

\begin{tabular}{lccccccc}
\hline Layer number & Soil layer & Layer thickness $(\mathrm{m})$ & Unit weight $\left(\mathrm{kN} / \mathrm{m}^{3}\right)$ & $v(-)$ & $E(\mathrm{MPa})$ & Cohesion $(\mathrm{kPa})$ & Friction angle $\left(^{\circ}\right)$ \\
\hline 1 & Fill above rolling layer & 0.5 & 21.8 & 0.17 & 5.1 & 45 & 28 \\
2 & Roadbed filling & 2.5 & 16.1 & 0.23 & 3.1 & 16 & 19 \\
3 & Filling under the bed & 1.5 & 19.8 & 0.29 & 3.4 & 17 & 19 \\
4 & Roadbed & 1.3 & 20.3 & 0.23 & 4.4 & 17 & 19 \\
5 & Surface layer & 0.8 & 22.8 & 0.19 & 12.9 & 48 & 35 \\
6 & Micro-pile & - & 78.0 & 0.30 & 200000 & - & - \\
\hline
\end{tabular}

center of the subgrade. In the three considered working conditions-roadbed construction, roadway operation, and micro-pile treatment-the maximum horizontal displacement directly below the toe was $4.05 \mathrm{~cm}, 1.37 \mathrm{~cm}$, and $0.03 \mathrm{~cm}$, respectively. The maximum horizontal displacement at the toe was $1.61 \mathrm{~cm}, 3.81 \mathrm{~cm}$, and $0.03 \mathrm{~cm}$, respectively. Finally, the maximum horizontal displacement at the shoulder was $6.54 \mathrm{~cm}, 2.53 \mathrm{~cm}$, and $0.06 \mathrm{~cm}$, respectively.
No micro-piles were added during the operation period, and a large portion of the foundation soil was compacted by roadbed filling and vehicle loads. During this period, the horizontal displacement of the center of the embankment was zero, and the maximum vertical displacement was $21.43 \mathrm{~cm}$. However, over time, both the horizontal and vertical displacements at the toe of the embankment slope tended to increase. 


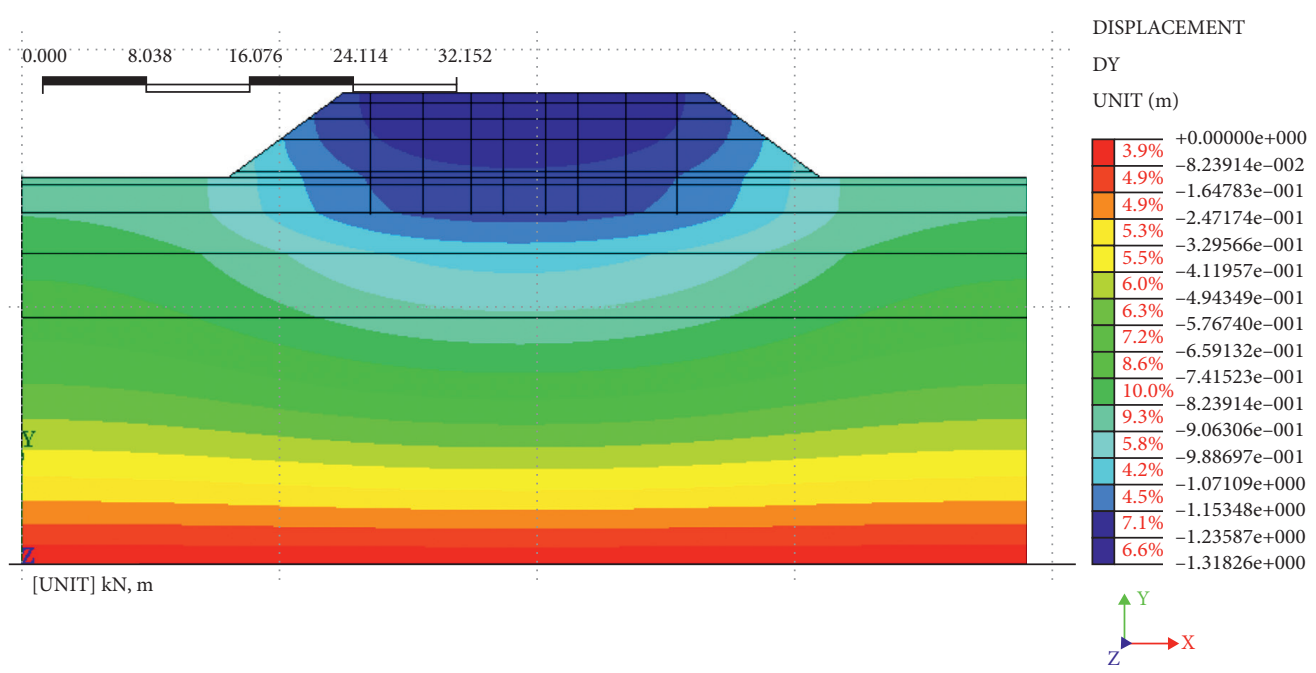

FIGURE 5: Model results for vertical displacement during subgrade filling.

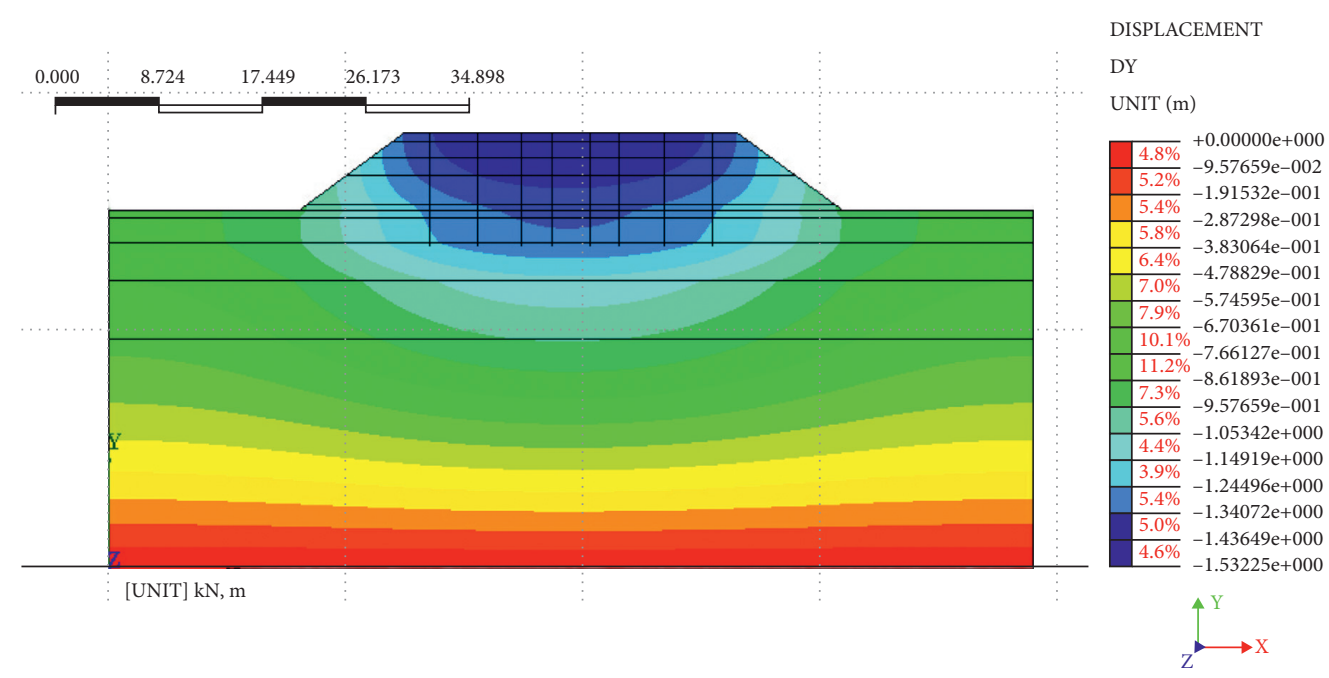

FIGURE 6: Model results for vertical displacement during roadway operation.

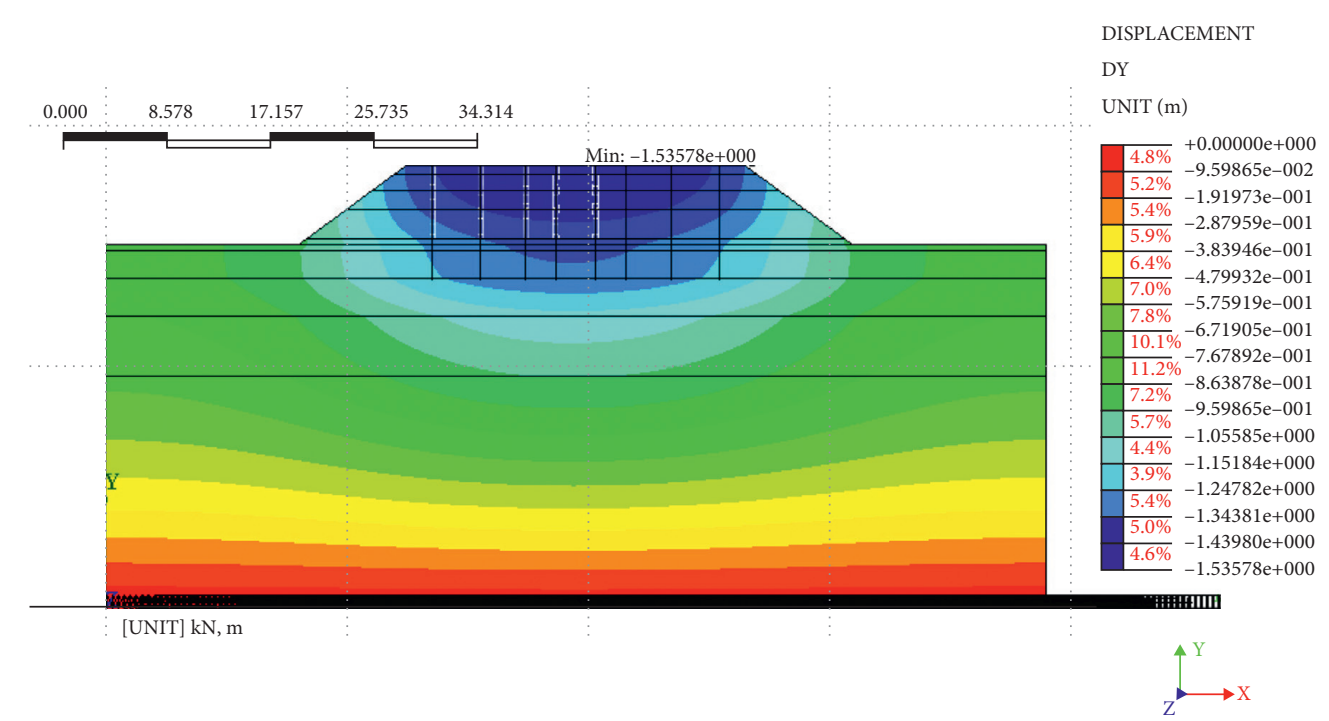

FIGURE 7: Model results for vertical displacement following micro-pile treatment. 
TABle 3: Comparison of the deformation monitoring value and the deformation value calculated by the numerical simulation.

\begin{tabular}{|c|c|c|c|c|c|c|}
\hline \multirow{4}{*}{ Condition } & \multicolumn{6}{|c|}{ Deformation $(\mathrm{cm})$} \\
\hline & \multicolumn{3}{|c|}{ Converted monitoring value } & \multicolumn{3}{|c|}{ Analogous simulation value } \\
\hline & \multicolumn{2}{|c|}{$X$} & \multirow{2}{*}{$\begin{array}{c}Y \\
\text { Center }\end{array}$} & \multicolumn{2}{|c|}{$X$} & \multirow{2}{*}{$\begin{array}{c}Y \\
\text { Center } \\
\end{array}$} \\
\hline & Slope foot & Road shoulder & & Slope foot & Road shoulder & \\
\hline Filling completed & - & - & - & 1.61 & 6.54 & 131.83 \\
\hline Operation period & 4.01 & 2.52 & 25.6 & 3.81 & 2.53 & 21.43 \\
\hline After treatment & 0.02 & 0.08 & 0.25 & 0.03 & 0.06 & 0.35 \\
\hline Reduced deformation & $99.50 \%$ & $96.83 \%$ & $99.02 \%$ & $99.21 \%$ & $97.63 \%$ & $98.37 \%$ \\
\hline
\end{tabular}

Note. No monitoring data were collected during the filling period.

\section{Comparative Analysis}

Table 3 summarizes the simulation calculation results which show that the deformation of the road shoulder and the center of the roadbed has the law of roadbed construction $>$ roadway operation period $>$ post-micro-pile treatment. It shows that the compression and consolidation of the fill account for most of the settlement and deformation of the roadbed in the whole life cycle. Both the monitoring data and simulation calculations show that the maximum settlement of the roadbed center is far greater than the maximum deformation of the slope toe and the shoulder in the $X$-direction. This shows that it is critical to consider the settlement of the center of the subgrade when monitoring subgrade deformation.

Both the monitoring data and simulation calculations also show that the maximum deformation of the slope toe, the shoulder, and the center of the roadbed decreases by more than 96\% after adding micro-piles. Specifically, the settlement of the roadbed center decreases by more than 98\% after micro-pile treatment, indicating that the micropile has a significant effect on mitigating the uneven settlement of the roadbed.

\section{Conclusion}

This article relies on the micro-pile to treat the uneven settlement of the roadbed. We use on-site monitoring and numerical simulation methods and analyze the stress and deformation characteristics of the subgrade before and after the micro-pile treatment. The conclusions are drawn as follows:

(i) We propose and use the deviation rate $P$ to check the new method of simulation results. The compression and consolidation of the filled soil account for most of the settlement and deformation of the roadbed in the whole life cycle.

(ii) Comparative analysis of monitoring and simulation results shows that the settlement of the center of the roadbed is a sensitive part of deformation monitoring. After piles are added, the deformation extremes at the toe, shoulder, and center of the roadbed are all reduced by more than $96 \%$.

(iii) Although the $P$ value verification method based on field monitoring and simulation trial calculation has achieved satisfactory results in parameter selection, there are still some limitations in specific operations. For example, the collection of on-site monitoring data is easily affected by external factors. The modeling process needs to rely on assumptions. Therefore, accurate collection of monitoring data and analysis of model influencing factors are the focus of future research.

\section{Data Availability}

The data used to support the findings of this study are available from the corresponding author upon request.

\section{Disclosure}

The preliminary results of this article have been published as a report manuscript of the "Southern African Transport Conference, Jul 2018." The link to the manuscript is as follows: http://www.satc.org.za/assets/2a_gao2.pdf.

\section{Conflicts of Interest}

The authors declare that they have no conflicts of interest.

\section{Acknowledgments}

This study was supported by the National Natural Science Foundation of China (grant nos. 11872311 and 51708043), Natural Science Basic Research Plan of Shaanxi Province of China (grant no. 2019JQ-680), and Special Fund for Basic Scientific Research of Central Colleges (Natural Sciences) (grant no. 300102219209).

\section{References}

[1] D. R. Shields, "Buckling of micropiles," Journal of Geotechnical and Geoenvironmental Engineering, vol. 133, no. 3, pp. 334-337, 2007.

[2] J. Gong, R. Chen, Y. Chen, G. Cheng, and J. Ying, "Prototype testing study on micropiles under lateral loading," Chinese Journal of Rock Mechanics and Engineering, vol. 23, pp. 3541-3546, 2004.

[3] Y. Hu, T. Wang, and L. Ma, "Research on anti-sliding characteristics of single double-row and composite anti-slide micropiles," Chinese Journal of Rock Mechanics and Engineering, vol. 31, pp. 1499-1505, 2012.

[4] F. Wang, H. Wu, C. Guo, and Z. Wu, "Evaluation of soil slope reinforced by micropiles based on acceleration response," 
Chinese Journal of Rock Mechanics and Engineering, vol. 38, pp. 3812-3821, 2019.

[5] X. Duan, J. Gao, Y. Men, and Q. Dong, "Study on model test of high and step slope pre-supported by micro pile group," Journal of disaster prevention and mitigation engineering, vol. 38, pp. 244-250, 2018.

[6] A. M. Alnuaim, M. H. El Naggar, and H. El Naggar, "Performance of micropiled rafts in clay: numerical investigation," Computers and Geotechnics, vol. 99, pp. 42-54, 2018.

[7] J.-S. Moon and S. Lee, "Static skin friction behavior of a single micropile in sand," KSCE Journal of Civil Engineering, vol. 20, no. 5, pp. 1793-1805, 2016.

[8] Z. Guo and L. Deng, "Field behaviour of screw micropiles subjected to axial loading in cohesive soils," Canadian Geotechnical Journal, vol. 55, no. 1, pp. 34-44, 2018.

[9] Z. Zhang and Y. Chen, "Model test and numerical analysis of micropile-MSE wall," Chinese Journal of Rock Mechanics and Engineering, vol. 36, pp. 987-996, 2017.

[10] Y. Wang, J. Feng, X. Xie, B. Lai, and T. Yang, "In-situ experimental study of anti-siding mechanism of micro-pile combined structure," Rock and Soil Mechanics, vol. 11, pp. 4226-4231, 2018

[11] S. Wu, Y. Gao, and A. Jin, "Study on reinforcement of micropile and rockbolt for an unstable high-steep road cut slope," Chinese Journal of Rock Mechanics and Engineering, vol. 24, pp. 3954-3958, 2005.

[12] Z.-S. Fang, T. Zhi, and X. Zhao, "Experimental study on the function of coupling beams for micropiles in landslip," Geotechnical Investigation, vol. 40, pp. 5-9, 2012.

[13] J. Liang, Y. Men, and S. Shi, "A model experiment on the steel reinforcement of micro-pile groups in landslide control," Journal of Geologiccal Hazard and Environment Preservation, vol. 24, pp. 74-79, 2013.

[14] B. Zhu, H. Hu, Y. Zhang, Q. Chen, and S. Zhang, "Application of steel-tube bored grouting antisliding retaining wall to treatment of landslide K108 in beijing-zhuhai Expressway," Chinese Journal of Rock Mechanics and Engineering, vol. 25, pp. 399-406, 2006.

[15] B. Zhu, S. Sun, and J. Zheng, "In-situ testing study of accumulative formation landslide reinforced by micropile group," Chinese Journal of Rock Mechanics and Engineering, vol. 30, pp. 2858-2864, 2011.

[16] M. Esmaeili, M. G. Nik, and F. Khayyer, "Experimental and numerical study of micropiles to reinforced high railway embankments," International Journal of Geomechanics, vol. 13, pp. 724-744, 2013.

[17] Z. Chen, L. Mei, and G.-X. Mei, "Numerical simulation of lateral bearing capacity of flexible micropile," Rock and Soil Mechanics, vol. 32, pp. 2219-2224, 2011. 